Michelle

KP A/130218075

\title{
Good Corporate Governance Role in Facing Economic Disruption in Indonesia
}

Exponential advancement in technology has lead to an economic disruption all over the world including in Indonesia. Facing the uncertain nature of the economies, companies in Indonesia must be able to adapt and innovate. However, this effort must be accompanied by Good Corporate Governance to earn trust from the stakeholders. To be able to survive and generate profits, companies in Indonesia must constantly accomplish new values and increase their performance. Human resource management is also an important aspect to be paid attention to.

Compared to Indonesia's 72nd position in 2017, Indonesia's ease of doing business rank is down to 73rd in 2018. Indonesia struggles to improve the ranking due to the consistently low exports and imports since 2015. As the world faced uncertainty regarding the global financial, the condition of the world economy in 2018 tends to be drowsy and uneven. Furthermore, the trade relations between countries have weakened leading to the low volume of world trade. Within the period of economic disruption, the competition grew tighter and many companies are obligated to make continuous changes to optimize their strategies and achieve profit maximization. But still, some fail along the way due to the increasingly global competitive environment (Tayibnapis et al., 2019).

In response to these circumstances, Indonesia established the Making Indonesia 4.0 initiative which is a roadmap to prepare Indonesia for the Industry 4.0. Making Indonesia 4.0 consists of five priority industrial sectors to strengthen the industrial structure in Indonesia. Strategies and goals are set to be achieved in 2030 in each industry sectors priority including food and beverages, chemical, textile, automotive, and electronics.

The implementation of Good Corporate Governance can direct and control the transformation of corporate resources to create added value for all stakeholders, therefore creating sustainable business success. Through GCG, one can earn numerous benefits, such as ensuring the establishment of corporate culture, the presence of information disclosure, an effective audit system, and risk control that alludes to GCG standards. GCG practices are expected to meet three dimensions: compliance, conformance, and performance by building awareness, disseminating a code of conduct, implementing GCG standards, GCG assessment, 
full disclosure and full transparency, and action plans. Companies also need to have a clear system so the direction and measurement for the company become clear (Tayibnapis et al., 2019).

There was an increase of 5,898 business entities in the large and medium industries between 2014 and 2017. Not only that, but the small industry has also increased from 2014 to 2017, with an addition of 970 thousand small business entities. Investment in the manufacturing industry sector in 2014 was IDR 195.74 trillion and rose to IDR 274.09 trillion in 2017. Meanwhile, in the first semester of 2018, investment in the manufacturing industry sector reached IDR 121.56 trillion (Ministry of Industry of the Republic of Indonesia, 2018).

The development of the digital economy has lead to an increase in the recruitment of new workers with information and technology skills especially in the sectors which use high technology as the industrial sector and mining sector. So, fast-moving digital technology advancement demands a change of expertise, considering that the skills currently possessed by workers may not be needed in the future. Digital trends create many new employment as we can see from the increase of 2.67 in employment opportunities from 2017 to 2018. However, according to the Labor Development Index, the quality of the workforce in Indonesia is still not maximum (Tayibnapis et al., 2019).

To be able to survive and create value amidst the economic disruption and high competition in the market, companies are very dependent on the ability to take advantage of technological advancement. Also, companies must be able to forecast their future so that they can create a clear framework to execute their strategies appropriately. The company structure has to be aligned with the company strategy and every work unit should have a clear function and role in the company to reach the collective goals. However, there's an issue that always emerges when a company tries to execute new strategies, that is the readiness of the company to align the strategy with the company structure, process, competencies, and culture. Hence, a regular self-assessment is needed for every company to adjust their competencies with their strategy (Tayibnapis et al., 2019).

VUCA (volatility, uncertainty, complexity, and ambiguity) that the world experienced arises from external factors such as trade war and globalization, also internal factors from the company itself. Therefore, business and human resource transformation are mandatory. PT. BNI, Tbk. and PT. Hartono Plantation Indonesia (HPI-Agro) are two companies that successfully have realized business and human resource transformation. PT BNI, Tbk. has 
successfully executed banking digital transformation through mobile banking, digital loans, etc. Meanwhile, HPI-Agro has implemented 9 business transformations. Transformation can be done from various aspects based on the scale of transformation. The transformation process has to be in line with business ethics and GCG principles which are transparency, accountability, responsibility, independence, and fairness. If the transformation process succeeds then companies can maintain their existence and relevance (Tayibnapis et al., 2019).

Recently, awareness for implementing GCG as tools and guidelines that can add competitive advantage has increased in Indonesia. Many companies have consistently made GCG the operational foundation so they can implement their strategies and management systems correctly, therefore raises trust from stakeholders. This is proven by the fact that companies that have already implemented GCG show significant progress in terms of their output, outcome, and impact. Furthermore, GCG can encourage companies to continuously create new values, therefore, improving company performance and increasing investors' trust for the company. In consequence, GCG becomes a very important consideration in the investment decision-making process (Tayibnapis et al., 2019).

\section{REFERENCES}

Hidayatno, A., Destyanto, A. R., \& Hulu, C. A. (2019). Industry 4.0 technology implementation impact to industrial sustainable energy in Indonesia: A model

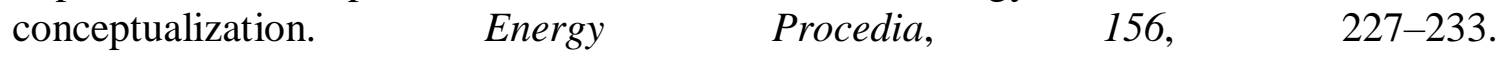
https://doi.org/10.1016/j.egypro.2018.11.133

Tayibnapis, A. Z., E. Wuryaningsih, L., \& Gora, R. (2019). Companies in Indonesia in the vortex of global economic disruption. 308(Insyma), 174-177. https://doi.org/10.2991/insyma-19.2019.45 